\section{The Closing of China? Possible Implications for Universities Worldwide}

\section{Philip G. Altbach and Hans de Wit}

Philip G. Altbach is research professor and founding director, and Hans de Wit is professor and director, Center for International Higher Education, Boston College, US. E-mails: altbach@bc.edu and dewitj@ bc.edu.

$\mathrm{T}$ The news that China's constitution will be amended so that president Xi Jinping can be president beyond his current second term is only the latest indication of fundamental political change taking place. Experts have noted that president Xi has amassed the most power since Mao Zedong, and seeks long-term authority to carry out his policies. While higher education, research, and internationalization are far from the center of contemporary political developments, they will unquestionably be affected and may be "collateral damage."

Over the past several decades, we have seen a dramatic growth in higher education internationalization, student mobility in and out of China, and cross-border presence of foreign universities in China, all contributing to the establishment of world-class universities and a significant rise of Chinese universities in the rankings. Current changes at the top in China will have lasting implications for both Chinese higher education and for China's academic relations with the rest of the world, and might seriously impact what has been accomplished so far. It is essential that the higher education community, inside China as well as globally, pay careful attention to the likely prospects.

\section{INTERNAL DEVELOPMENTS}

When considered together, recent developments show significant change in the Chinese academic landscape of the past half-century. The internet has been tightened, making it more difficult to access information freely. Virtual Private Networks (VPN) used to permit reasonably easy access to the global internet for those able to manipulate the system-this is no longer the case. In addition, many have noted that more material considered "sensitive" has been eliminated from the web in China. While such restrictions affect the social sciences most directly, the entire academic community is impacted by both the perception and the reality of a lack of access to the world's knowledge.

While Communist Party supervision of universities has traditionally been a central part of academic governance, it has recently been strengthened. The role of ideological education as part of the university curriculum has been enhanced, including the "thought of Xi Jingping." Emerging programs of US-style liberal education at some of China's elite universities have come under criticism, and some are trying to think of a less "provocative" name and perhaps making changes in the relevant curriculum.

\section{External Reactions}

There has also been some reaction against aspects of China's higher education international initiatives. Criticism of some of the more than 480 Confucius Institutes, established by the Chinese government worldwide and primarily located on university campuses, is growing, and a few have been closed down by host institutions. There has also been criticism of what is seen by some as heavy-handed Chinese involvement in Africa, including in higher education. A major controversy is taking place in Australia, where Chinese agencies are accused of trying to influence Australian researchers working on China and engaging in other perceived interference, as well as putting pressure on Chinese

\section{While Communist Party supervision of universities has traditionally been a cen- tral part of academic governance, it has recently been strengthened.}

students in that country, as well as elsewhere, to spy on fellow students and scholars. A Dutch university cancelled a planned branch campus in China after concerns about academic freedom were raised in the Netherlands. And a storm of protest took place when a prominent British publisher eliminated some content from its journals deemed objectionable by Chinese authorities. The content was restored after complaints by Western academics. What is significant here is that Chinese authorities are increasingly attempting to interfere overseas-and that there is growing pushback by Western academics and institutions.

\section{IMPLICATIONS}

Of course, the most important implications of a "closing" of Chinese higher education will be on the universities. It will be more difficult for the top institutions to achieve true "world-class" status if their academic culture is infused with restrictions, problematic access to knowledge, and constraints on the emergence of a truly free and innovative academic culture. A restrictive academic environment will make it more difficult to attract talented foreign faculty to 
work in China, and it is likely that international students, especially at the graduate level, will be reluctant to study in China.

Meanwhile, there is an increase in the return rate of Chinese students and scholars who have studied abroad, according to the president of the National Natural Science Foundation of China. "Just Io years ago, the flow of talent was at about seven Chinese students leaving for every one that came back. Now it's six [students] returning in every seven," he said, adding, "The brain drain is almost over" (Times Higher Education, March I, 20I8). This trend is unlikely to continue as circumstances change. Further, that comment was limited to STEM fields and mainly to undergraduates. According to most statistics, 70 to more than 80 percent of Chinese doctoral degree holders are not returning home-a number that has been holding steady.

\section{CONCLUSION}

After decades of attempting to create a more open academic environment, it is clear that China is rapidly changing direction. The new direction is inevitable, given recent political developments. China's investment of billions of dollars in the upgrading of its top universities to create "world-class" institutions may be, at least in part, put at risk. China's internationalization efforts of recent years will be significantly damaged. The investments made by Western universities in developing branch campuses and other academic relationships in China may be threatened-and very likely will slow down. China's efforts to convince Chinese students who have studied abroad to return, particularly those at the masters and doctoral levels, will be less successful, as many will question what is happening to academic life in China.

Following Brexit, the election of Donald Trump in the United States, and the general challenges of nationalism and populism globally, we are entering uncharted academic territory. China, however, is different. There are few dissident voices and no challenges to central authority. In the end, there might be losses on both sides. Chinese universities will be seriously hampered in their move to rise to world-class standards, academic freedom will be further away than ever, and collaboration with Western universities will become more difficult. Chinese authorities seem not to worry much about these risks. They look more to higher education in emerging and developing countries, which as a sector is perhaps more dependent on collaboration with China. In the end, China may end up in a gigantic periphery.

DOI: http://dx.doi.org/ıo.6oI7/ihe.2018.93.10376

\section{Have Chinese Universities Hit a Plateau?}

\section{Alex Usher}

Alex Usher is president, Higher Education Strategy Associates, Toronto, Ontario, Canada. E-mail: ausher@higheredstrategy.com.

$T^{1}$ he massive investments in higher education made by the People's Republic of China are well known. Since the ascension to power of Deng Xiaoping in I978, the country has placed an enormous emphasis on developing its science and technology capabilities, and universities have been central to this effort. For nearly 20 years, the " 985 " project has been providing billions of yuan to top institutions to make them "world-class." In the first two phases alone-that is, from I998 to 2007-expenditures across 39 recipient universities were estimated at RMB 33 billion, or roughly US\$13 billion in today's dollars at purchasing power parity (PPP). However, measuring the extent of this investment consistently has been difficult, as China does not report higher education expenditures to UNESCO and individual universities have been traditionally rather opaque about their finances.

So it is of some interest that, in 20I2, the Chinese government published a "transparency directive" for the higher education sector, which included a demand that institutions publish some type of annual financial report. Compliance has not been roo percent, and the data does not contain a high level of detail; nevertheless, at most of the major institutions, we have five full years of such information (2012-20I6). And this new data tells three rather important stories.

\section{Top Chinese Universities Are Rich}

The first is that top Chinese universities-that is, the largest of the Cy universities that are sometimes described as "China's Ivy League" - are really quite wealthy, with financial muscle comparable to some top US institutions. The largest institution, Tsinghua University, had annual expenditures of RMB I3.7 billion in 20I6, which translates to about US\$3.57 billion at PPP, making it larger in raw terms than both MIT (US\$3.34 billion in 20I4) and Yale University (US\$3.36 billion). The next largest institution, Peking University, had expenditures of roughly US\$2.45 billion in 20I6, which puts it in roughly the same category as Caltech and Washington University St. Louis. Zhejiang University and Shanghai Jiao Tong University, the two next biggest, have expenditures of US\$2.3 billion and US\$2.I billion, respectively. Fudan University, in fifth place, has expenditures of US\$I.5 billion, which is roughly equivalent to those of Princeton University. 